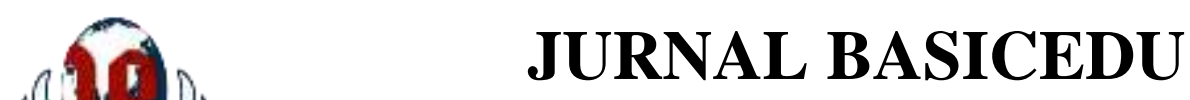

Volume 5 Nomor 6 Tahun 2021 Halaman 5753 - 5760

Research \& Learning in Elementary Education

https://jbasic.org/index.php/basicedu

PAHLAMAN

\title{
Implementasi Pendidikan Multikultural melalui Mata Pelajaran PPKn untuk Mendukung Sikap Toleransi Siswa dalam Masyarakat Multikultur
}

\author{
Shilmy Purnama \\ Pendidikan Pancasila dan Kewarganegaraan, Universitas Tanjungpura, Indonesia \\ E-mail: shilmypurnama@fkip.untan.ac.id
}

\begin{abstract}
Abstrak
Kondisi keberagaman yang dimiliki oleh bangsa Indonesia memiliki dampak positif dan negatif. Salah satu tantangan yang dihadapi oleh bangsa multikultur adalah rentang terjadinya konflik horizontal. Oleh karena itu, seluruh lapisan masyarakat harus menjunjung tinggi sikap toleransi sebagai upaya preventif. Pentingnya sikap toleransi yang dimiliki oleh masyarakat ini dirasa perlu dikembangkan sejak dini melalui jalur Pendidikan. Penelitian ini bertujuan untuk mendeskripsikan implementasi Pendidikan Multikultural pada mata pelajaran PPKn untuk mendukung sikap toleransi siswa. Penelitian menggunakan pendekatan kualitatif dan metode deskriptif. Hasil penelitian menunjukkan bahwa implementasi Pendidikan Multikultural tidak menjadi mata pelajaran sendiri yang terpisah, melainkan diintegrasikan ke dalam mata pelajaran PPKn. Penerapannya diawali dengan merumuskan perencanaan pembelajaran berupa RPP dengan cara melakukan analisis KI$\mathrm{KD}$, memilih materi mana yang cocok disisipkan nilai Pendidikan Multikultural sehingga tercermin dalam tujuan pembelajaran dan indikator pencapaian kompetensinya. Setelah itu, dalam proses pelaksanaan pembelajarannya pun, guru bisa menyampaikan materi yang telah dipilih yang berkaitan dengan Pendidikan Multikultural seperti keberagaman Indonesia, atau materi umum. Materi umum diterapkan dengan metode diskusi atau simulasi yang tetap mencerminkan nilai-nilai toleransi sebagai perwujudan dari Pendidikan Multikultural.
\end{abstract}

Kata Kunci: Pendidikan Multikultural, PPKn, sikap toleransi.

\begin{abstract}
The diversity that is owned by the Indonesian people has positive and negative impacts. One of the challenges faced by multicultural nations is the range of horizontal conflicts. Therefore, all levels of society must uphold the attitude of tolerance as a preventive measure. The importance of the attitude of tolerance possessed by this community is felt to be developed from an early age through education. This study aims to describe the implementation of Multicultural Education in Civic Education subject to support students' tolerance. The study used a qualitative approach and descriptive method. The results of the study indicate that the implementation of Multicultural Education is not a separate subject, but is integrated into Civic Education subject. Its application begins with formulating a learning plan in the form of lesson plan by analyzing the KI-KD, choosing which materials are suitable for inserting the value of Multicultural Education so that it is reflected in the learning objectives and indicators of competency achievement. After that, in the process of implementing the learning process, the teacher can convey the selected material related to Multicultural Education such as Indonesian diversity, or general material. The general material is applied by discussion or simulation methods that still reflect the values of tolerance as the embodiment of Multicultural Education.
\end{abstract}

Keywords: Multicultural Education, Civic Education, tolerance.

Copyright (c) 2021 Shilmy Purnama

$\checkmark$ Corresponding author :

Email : shilmypurnama@fkip.untan.ac.id

DOI : https://doi.org/10.31004/basicedu.v5i6.1561

ISSN 2580-3735 (Media Cetak)

ISSN 2580-1147 (Media Online)

Jurnal Basicedu Vol 5 No 6 Tahun 2021

p-ISSN 2580-3735 e-ISSN 2580-1147 
5754 Implementasi Pendidikan Multikultural melalui Mata Pelajaran PPKn untuk Mendukung Sikap Toleransi Siswa dalam Masyarakat Multikultur - Shilmy Purnama

DOI: https://doi.org/10.31004/basicedu.v5i6.1561

\section{PENDAHULUAN}

Keberagaman budaya, suku, ras, etnis, dan agama yang dimiliki negara Indonesia menjadikan Indonesia sebagai salah satu negara multikultur terbesar di dunia. Multikultur ialah kondisi keberagaman yang dimiliki masyarakat dikarenakan perbedaan agama, ras, suku, etnis, budaya, bahasa, dan sebagainya. Masyarakat multikultural merupakan kondisi masyarakat yang terdiri atas beberapa jenis kelompok budaya, nilai, organisasi sosial, dan adat kebiasaan(Parekh, 2008). Konsep keberagaman dan multikulturalisme ini pun tercermin dalam semboyan negara Bhinneka Tunggal Ika sebagai jati diri bangsa yang alamiah menggambarkan kondisi keberagaman sosial budaya bangsa Indonesia dan dipahami sebagai konsep multikulturalisme (Winataputra, 2012). Kondisi keberagaman yang dimiliki oleh bangsa Indonesia memiliki dampak positif dan negatif. Salah satu tantangan yang dihadapi oleh bangsa multikultur adalah rentang terjadinya konflik horizontal. Hal ini dikarenakan implikasi dari adanya keadaan multikultural adalah adanya kelompok minoritas dan mayoritas. Realita yang terjadi sampai saat ini adalah kelompok minoritas yang termarjinalkan oleh kelompok mayoritas karena memiliki status sosial ekonomi yang lebih tinggi. Kecenderungan adanya perasaan superioritas, anggapan bahwa kelompok minoritas memiliki derajat yang lebih rendah, dan adanya klaim kelompok dominan bahwa sebagai akses sumber daya merupakan hak mereka (Nur Hidayah, 2006).

Oleh karena itu, seluruh lapisan masyarakat harus menjunjung tinggi sikap toleransi sebagai upaya preventif. Pentingnya sikap toleransi yang dimiliki oleh masyarakat ini dirasa perlu dikembangkan sejak dini melalui jalur pendidikan, baik jenjang pendidikan dasar, menengah, dan tinggi. Upaya untuk mendukung sikap toleransi diberikan pada jenjang pendidikan dasar sebagai pondasi yang dapat dijadikan bekal para generasi muda untuk bisa hidup berdampingan di lingkungan masyarakat yang multikultur. Sikap toleransi pada siswa sekolah dasar dapat diajarkan melalui kegiatan intra kurikuler, ko-kurikuler, dan ekstra kurikuler. Kegiatan intra kurikuler berupa pembelajaran pada mata pelajaran PPKn (Pendidikan Pancasila dan Kewarganegaraan).

Upaya melalui jalur Pendidikan ini dilakukan sebagai upaya preventif yang dapat mencegah terjadinya gesekan atau konflik horizontal akibat kondisi keberagaman yang dimiliki masyarakat Indonesia. Upaya mewujudkan kehidupan masyarakat yang harmonis dilakukan dengan strategi mengetahui, menghargai, dan menanamkan kepekaan terhadap kondisi keberagaman sosial budaya (Supardan, 2004). Bersamaan dengan upaya di bidang pendidikan, pemerintah melalui Kementerian Pendidikan sebaiknya mengadopsi Pendidikan multikulturalisme untk diterapkan ke dalam Pendidikan di persekolahan dan memasukkannya ke dalam kurikulum sekolah (Suparlan, 2002). Misalnya dalam proses pembelajaran dengan kondisi siswa yang beragam latar belakangnya, diupayakan memberikan pengetahuan dan pemahaman akan kondisi budaya yang berbeda tersebut. Setelah siswa mengetahui dan memahami akan kondisi sosial budaya yang beragam tersebut, maka siswa dibimbing untuk bisa hidup berdampingan dengan cara saling menghargai perbedaan diantara teman-teman kelas dan sekolahnya. Denga demikian, penerapan konsep ini diharapkan dapat dilaksanakan secara konsisten dan berkelanjutan sehingga dapat mengurangi resiko terjadinya konflik horizontal yang mungkin terjadi. Dengan kata lain, memperlakukan seluruh budaya dengan adil dan setara, maka tidak akan adanya dominasi budaya tertentu yang dapat menghambat pengembangan budaya minoritas(Blum, 2001). Siswa berada dalam posisi yang sejajar tanpa memperhatikan latar belakang sosial budayanya dalam setiap proses pembelajaran, terutama mata pelajaran PPKn yang bermuatan Pendidikan Multikultural. Pendidikakn Multikultural bisa membantu siswa agar memiliki paradigma yang mengakui akan adanya perbedaan pendapat dan pandangan budaya yang beragam, memiliki rasa bangga akan kekayaan kebudayaannya, memberikan pemahaman bahwa konflik nilai bisa menjadi pemicu timbulnya konflik antar masyarakat (Savage \& Armstrong, 1996). 
5755 Implementasi Pendidikan Multikultural melalui Mata Pelajaran PPKn untuk Mendukung Sikap Toleransi Siswa dalam Masyarakat Multikultur - Shilmy Purnama

DOI: https://doi.org/10.31004/basicedu.v5i6.1561

Dalam setiap proses pembelajaran, siswa belajar untuk bersikap menghargai, humanis, dan mengakui keberagaman yang ada dalam lingkungannya. Hal ini dikarenakan, penanaman nilai menghargai, menghormati, toleransi, dan simpati menjadi bekal yang sangat diperlukan bagi siswa untuk menciptakan kedamaian dan penanggulangan konflik di kemudian hari. Sikap toleransi ini adalah pengakuan terhadap perbedaan dalam kemajemukan yang hanya mungkin terwujud dengan adanya kebebasan dan toleransi serta penerimaan tindakan atau pandangan orang lain (Kalidjernih, 2010). Proses pembelajaran yang dimaksud adalah proses pembelajaran mata pelajaran PPKn yang bermuatan Pendidikan Multikulutral yang harus dilaksanakan oleh guru Bersama-sama dengan siswa di kelas secara konsisten. Pembelajaran ini harus sesuai dengan tujuan pembelalaran yang ingin dicapai yang telah dirumuskan sebelumnya. Proses perumusan perencanaan pembelajaran dilakukan oleh guru untuk mengintegrasikan nilai-nilai yang terkandung dalam Pendidikan Multikultural ke dalam mata pelajaran PPKn. Oleh karena itu, guru harus memiliki kemampuan dalam merumuskan perencanaan pembelajaran, seperti merumuskan Rencana Pelaksanaan Pembelajaran (RPP), sampai melaksanakan RPP yang telah dibuat tersebut ke dalam proses pembelajaran yang bermakna Pendidikan Multikultural. Selain itu, kemampuan guru yang dapat menunjang keberhasilan implementasi Pendidikan Multikultural adalah guru harus memiliki pengetahuan dan pemahaman akan latar belakang budaya siswanya yang berbeda. Sebagaimana yang dikemukakan Elshamawi (Aly, 2005), menawarkan kompetensi multikultural yang harus dimiliki oleh guru, diantaranya guru harus mempunyai nilai dna hubungan sosial yang luas agar guru bisa memiliki kompetensi sosial yang baik antara guru dengan siswa, maupun antara guru dengan sesama guru lainnya. Perbedaan latar belakang siswa membuat adanya keberagaman yang pelru dikelola secara fleksibel oleh guru dan tidak menjadi pemicu konflik. Sebelum menuntut siswanya agar memiliki toleransi, alangkah baiknya jika guru memahami dan menghargai perbedaan latar belakang sosial budaya seluruh siswanya. Jika ternyata realita yang ada, terdapat beberapa siswa yang menjadi minorita, guru harus bisa mengantasipasi hal ini dan tidak menyebabkan siswa merasa termarjinalkan. Selain itu, guru dituntut bersikap visioner, artinya memiliki visi dan tujuan yang mengarah pada masa depan yang lebih baik dengan cara bekerjasama dengan semua pihak terkait pembelajaran.

Hal ini sejalan dengan pendapat (Bank, 1984) tentang kompetensi multikultural lain yang harus dimiliki oleh guru, yaitu:

1. Peka pada perilaku etnik yang dimiliki siswa;

2. Tanggap jika ada kecenderungan kontroversi pada materi pembelajaran yang akan disampaikan;

3. Mengakomodir metode pembelajaran secaraberkelompok untuk memfasilitasi keberagaman etnik di kelas.

Selain guru harus memiliki pengetahuan secara kognitif mengenai materi PPKn yang ingin disampaikan dalam pembelajaran, guru juga harus memiliki keterampilan penunjang dalam mengimplementasikan Pendidikan Multikultural. Guru harus memiliki pengetahuan tentang kondisi keberagaman siswa, darimulai latar belakang sosial budaya siswanya, memfasilitasi kondisi keberagaman tersebut, menggunakan metode pmebelajaran yang bisa mengakomodir keberagaman siswa, sampai mempertimbangkan kemungkinan penyampaian materi yang dianggap sensitif bagi siswa tertentu. Kemampuan dan keterampilan ini menjadi faktor pendukung keberhasilan penerapan Pendidikan Multikultural melalui mata pelajaran PPKn di sekolah. Implementasi Pendidikan Multikultural diharapkan dapat mendukung sikap toleransi siswa, terutama siswa di sekolah dasar. Sehingga siswa sudah terbiasa dan memiliki karakter toleransi yang kuat ketika mereka berada di lingkungan masyarakat dan berbangsa serta bernegara nantinya. Sikap tolernasi yang dimaksud bukan hanya berupa menghargai perbedaan, akan tetapi mencerminkan sikap yang lebih terbuka dan penuh kedamaian. Seperti yang dikemukakan oleh (Tillman, 2004) tentang butir-butir refleksi dari karakter toleransi adalah:

1. Kedamaian adalah tujuan;

2. Toleransi adalah terbuka dan reseptif pada indahnya perbedaan; 
5756 Implementasi Pendidikan Multikultural melalui Mata Pelajaran PPKn untuk Mendukung Sikap Toleransi Siswa dalam Masyarakat Multikultur - Shilmy Purnama

DOI: https://doi.org/10.31004/basicedu.v5i6.1561

3. Toleransi menghargai individu dan perbedaan;

4. Toleransi adalah saling menghargai satu sama lain;

5. Benih dari intoleransi adalah ketakutan dan ketidakpedulian;

6. Benih dari toleransi adalah cinta;

7. Jika tidak ada cinta tidak ada toleransi;

8. Toleransi berarti menghadapi situasi sulit; dan

9. Toleransi terhadap ketidaknyamanan hidup dengan membiarkan berlaku, ringan, dan membiarkan orang lain.

Penelitian ini berisi kajian tentang implementasi Pendidikan Multikultural di sekolah dasar yang berada di lingkungan mutlikultur. Pendidikan Multikultural yang diimplementasikan disini, bukanlah sebuah mata pelajaran yang berdiri sendiri. Akan tetapi Pendidikan Multikultural yang diintegrasikan ke dalam mata pelajaran lain di sekolah, khususnya PPKn. Pendidikan Multikultural dan PPKn memiliki tujuan yang sama yaitu ingin menumbuhkembangkan sikap toleransi siswa di sekolah sehingga bisa menjadi warga negara yang baik yang bisa hidup berdampingan di lingkungan masyarakat di tengah keberagaman atau multikultur.

\section{METODE PENELITIAN}

Secara umum, penelitian ini dilakukan dengan menggunakan pendekatan penelitian kualitatif dan metode deskriptif, karena ingin menggambarkan kondisi atau peristiwa yang terjadi di lapangan. Lokasi penelitian di SDN 87 Singkawang Kalimantan Barat. Subjek penelitian adalah kepala sekolah, dua orang guru mata pelajaran PPKn, dan siswa Kelas IV dan V. Data penelitian diperoleh dengan teknik wawancara, observasi, dan studi dokumentasi. Wawancara dilakukan kepada Kepala Sekolah, guru PPKn, dan beberapa siswa sebagai perwakilan penelitian. Observasi dilakukan dengan mengamati proses pembelajaran PPKn di kelas yang dilakukan oleh kedua guru PPKn, sedangkan studi dokumentasi dilakukan dengan menghimpun berbagai data penunjang penelitian berupa dokumen perencanaan pembelajaran, evaluasi, data keberagaman siswa di sekolah. Data penelitian yang telah diperoleh kemudian dianalisis dengan cara reduksi data untuk dilakukan seleksi data yang relevan dengan penelitian, disajikan berupa deskripsi dan disimpulkan (Huberman, 2014).

\section{HASIL DAN PEMBAHASAN}

Pada tahun 2020, Kota Singkawang mendapat predikat kota paling toleran kedua di Indonesia, setelah Salatiga, berdasarkan hasil survei Setara Institute. Hal ini sejalan dengan kondisi masyarakat kota Singkawang yang beragam dari segi agama, ras, etnik, budaya, dan bahasanya. Akan tetapi, masyarakat kota Singkawang dapat hidup berdampingan dan saling menghargai perbedaan tersebut. Setiap tahunnya, kota Singkawang akan merayakan hari besar keagamaan berdasarkan agam yang dianut oleh masyarakatnya. Perayaan hari besar keagamaan ini menjadi momen yang ditunggu setiap tahunnya karena menjadi ajang sukacita dan bukti bahwa masyarakat kota Singkawang bisa hidup berdampingan di tengah keberagaman. Perayaan hari besar keagamaan itu seperti, hari raya Idul Fitri dan Idul Adha, hari raya natal, dan hari raya imlek yang sudah terkenal ke penjuru Indonesia bahkan mancanegara.

Kondisi keberagaman yang dialami kota Singkawang ternyata terjadi di seluruh lapisan masyarakat dan di lingkungan persekolahan. Sekolah-sekolah umum di kota Singkawang terdiri dari siswa yang berasal dari berbagai suku, terutama suku besar yang tinggal di Singkawang, yaitu Tionghoa, Melayu, Dayak, dan suku lainnya. Begitu pula yang terjadi di SD Negeri 87 Singkawang sebagai salah satu sekolah dasar yang berada di wilayah masyoritas Melayu dan Tionghoa. Siswa-siswi di sekolah ini memiliki latar belakang sosial budaya 
yang berbeda. Sebagian siswa-siswa di sekolah ini berasal dari suku Melayu yang bergaam Islam, tetapi banyak juga yang berasal dari suku Tionghoa yang beragam Buddha dan Khonghucu. Kondisi keberagaman yang dialami sekolah ini menjadikan proses pembelajaran yang dilakukan harus bisa memberikan pengetahuan dan pemahaman akan pentingnya menghargai perbedaan dan sikap toleransi sejak dini. Salah satunya melalui proses pembelajaran PPKn yang secara khusus memuat nilai-nilai Pendidikan Multikultural. Mata pelajaran PPKn di seluruh jenjang persekolahan merupakan lingkungan belajar pendidikan formal yang terorganisasikan sebagai proses interaksi sosiokultural edukatif dalam konteks satuan Pendidikan, bukan hanya dibatasi pada konteks klasikal mata pelajaran atau mata kuliah (Setiawan, 2014). Maka mata pelajaran PPKn harus bisa diwujudkan dalam proses pembelajaran kajian Pancasila dan pembudayaan Pancasila untuk membangun watak bangsa Indonesia yang memiliki nilai-nilai multikultur.

Sebelum mengimplementasikan mata pelajaran PPKn yang bermuatan Pendidikan Multikultural, guru harus mempersiapkan perencanaan pembelajarannya. Berdasarkan hasil observasi dan wawancara yang diperoleh, proses perencanaan yang dilakukan memang hampir sama dengan mata pelajaran lainnya, yaitu dengan menyusun RPP terlebih dahulu. Akan tetapi, yang menjadi berbeda adalah proses penyususnan RPP ini harus diawali dulu dengan melakukan analisis Kompetensi Inti-Kompetensi Dasar dengan tujuan menetukan materi mana yang cocok untuk diintegrasikan dengan Pendidikan Multikultural. Analisis KI-KD ini biasanya dilakukan pada awal tahun pelajaran baru atau sebelum guru merumuskan RPP untuk semua proses pembelajaran. Melalui analisis KI-KD tersebut, guru akan menyusun indikator pencapaian kompetensi dan salah satu dari indikator tersebut bisa secara khusus mendeskripsikan sikap toleransi sebagai bentuk implementasi dari Pendidikan Multikultural. Setelah itu, guru bisa melakukan analisis kultural berdasarkan wilayah atau lingkungan dan aspek nilai kultural yang hidup di lingkungan siswa. Misalnya guru melakukan analisis latar belakang siswa yang akan diajarnya secara agama, ras, etnis, budaya, dan sebagainya. Apakah siswanya memiliki nilai kultural yang heterogen atau homogen.

Guru bisa melakukan pemetaan materi pembelajaran yang akan disampaikan. Secara sederhana, Pendidikan Multikultural paling cocok diintegrasikan ke dalam materi tentang keberagaman di Indonesia, akan tetapi bukan berarti tidak bisa dimuat dalam materi lainnya. Materi-materi lainnya pun masih bisa memuat nilai-nilai Pendidikan Multikultural. Integrasi nilai Pendidikan Multikultural ke dalam materi pembelajaran PPKn berkaitan dengan sejauh mana guru dapat menggunakan berbagai budaya dan kelompok untuk menggambarkan konsep kunci, generalisasi, teori dalam materi PPKn dengan tetap memperhatikan kelogisan (Banks \& Banks, 2013). Misalnya pada materi mata pelajaran PPKn kelas I tentang Hidup Rukun menekankan perkembangan psikologis-pedagogis siswa dengan menggunakan pendekatan tematik-ntegratif untuk mengembangkan karakter warga negara yang baik (Winataputra, 2015).Dalam kegiatan membaca doa di awal pelajaran dilaksanakan sesuai agama dan kepercayaan siswa masing-masing. Selain memuat nilai-nilai Pendidikan Multikutlural, pembacaan doa di awal pelajaran juga sebagai bentuk pelaksanaan pembelajaran PPKn yang berlandaskan Pancasila, khususnya sila pertama Ketuhanan Yang Maha Esa. Kondisi kelas yang beragam agamanya rawan terjadinya konflik, sehingga nilai Ketuhanan ini akan menjadi landasan dalam pelaskanaan toleransi antar umat Bergama di dalam kelas. Latar belakang sosial budaya siswa yang berbeda pun, akan menumbuhkan nilai kemanusiaan berdasarkan sila kedua Pancasila. Hal ini dibuktikan dengan adanya sikap salling menghormati, adil dalam memperlakukan orang tanpa melihat ras atau perbedaan lainnya (Kariyadi \& Suprapto, 2017).

Jika proses pembelajaran dilakukan dengan metode diskusi kelompok, siswa tidak memilih teman dan menghargai pendapat pun bisa dijadikan bukti pelaksanaan Pendidikan Multikultural di kelas.RPP yang disusun digunakan sebagai arahan atau pedoman dalam melaksanakan pembelajaran Pendidikan Multikultural di kelas. Di dalam RPP tersebut akan memuat tujuan pembelajaran, indikator pencapaian kompetensi, metode, serta nilai toleransi yang ingin ditampilkan. RPP mata pelajaran PPKn yang bermuatan Pendidikan 
5758 Implementasi Pendidikan Multikultural melalui Mata Pelajaran PPKn untuk Mendukung Sikap Toleransi Siswa dalam Masyarakat Multikultur - Shilmy Purnama

DOI: https://doi.org/10.31004/basicedu.v5i6.1561

Multikultural tidak memiliki bentuk dan struktur yang khusus, hanya memiliki nilai-nilai Pendidikan Multikultural, khususnya toleransi yang ingin dicapai.

Dalam mengimplementasikan RPP tersebut, guru dapat menggunakan beragam strategi pembelajaran, seperti dialog, simulasi, bermain peran, observasi, dan penanganan kasus (Aly, 2005). Beberapa strategi tersebut secara umum harus melibatkan partisipasi dan keaktifan siswa secara langsung, baik individu mapun berkelompok dengan tetap memperhatikan kesetaraan dan tanpa diskriminasi. Karena strategi pembelajaran berkelompok dengan kondisi siswa yang beragam bisa memicu terjadinya diskriminasi. Perlakuan diskriminasi ini berupa perlakuan berbeda karena adanya kelompok dominan berdasarkan ras, etnis, golongan, agama, jenis kelamin, dan sebagainya (Suparlan, 2004). Dalam pembelajaran Pendidikan Multikultural, strategi dialog mendalam dan berpikir kritis dikonsentrasikan untuk mendapatkan pengetahuan dan pengalaman, melalui dialog secara mendalam dan berpikir kritis (Al Hakim \& Untari, 2018). Strategi ini menuntut partisipasi dan keaktifan siswa secara fisik, kognitif, sosial, dan emosionalnya. Dengan demikian, siswa diharapkan dapat memiliki pengalaman belajar multikultural sehingga bisa memiliki kesadaran akan pentingnya hidup bertoleransi diantara masyarakat yang multikultur. Secara alamiah, siswa di dalam kelas sudah menggambarkan kondisi keberagaman di masyarakat multikultur. Oleh karena itu, guru bisa membimbing siswanya untuk berdiskusi tentang hal-hal apa saja yang menjadi sumbangan dari budaya lain temannya dalam hidup kita. Misalnya kegiatan pagi hari yang dilalui oleh para siswa, dimulai dari bangun pagi, mandi, dan sarapan. Sarapan mengkonsumsi nasi yang ttelah diolah oleh para petani yang berasal dari daerah lain dan suku lain. Siswa menggunakan pakaian yang berasal dari kain yang telah ditenun oleh pengrajin yang beragama lain. Hal ini sebagai gambaran bahwa semua orang dengan identitas budaya apapun menggunakan dan membutuhkan bantuan atau hasil karya orang lain dari budaya dan agama lain.

Selain itu, siswa juga bisa mempelajari baju daerah, rumah adat, bahasa daerah, dan lagu daerah lain berdasarkan asal daerah dari teman sekelasnya. Pengetahuan tentang bahasa daerah dan adat istiadat tersebut bisa menambah kemampuan adaptasi orang asing terhadap budaya masyarakat setempat (Budimansyah \& Suryadi, 2008). Pembelajaran budaya daerah setempat ini diharapkan dapat menjadi pembelajaran yang menarik dan menyenangkan bagi siswa. Sedangkan metode simulasi dan bermain peran bisa memfasilitasi siswa secara langsung untuk mengalami pembelajaran berperan sebagai orang-orang beragam tertentu, agama, dan etnik tertentu dalam kehidupannya sehari-hari. Contoh pelaksanaan dari kehidupan sederhana yang dialami siswa di lingkungan keluarga, sekolah, dan lingkungan sepermainan. Dalam kondisi tertentu, selain dituntut untuk mampu melakukan diskusi kelompok dalam pembelajaran, diadakan pula kegiatan dengan penyusunan panitia pelaksana yang melibatkan siswa dengan latar belakang sosial budaya yang beragam. Seluruh rangkaian proses pembelajaran inilah yang akan membuat siswa memahami dan mengalami nilai-nilai multikultural dalam proses pembelajaran PPKn, hal ini diperkuat dengan penggunaan bahasa Indonesia sebagai bahasa nasional dan bahasa persatuan pada setiap proses pembelajaran. Dengan berbahasa Indonesia yang baik dan benar, akan menguatkan rasa persatuan masyarakat Indonesia, khususnya siswa dalam hal ini karena memahami hal yang sama secara Bersama-sama (Meinarno, 2011).

Dengan demikian, siswa diharapkan akan memiliki pengetahuan dan pemahaman tentang eksistensi keberagaman di lingkungan sekitarnya. Di samping itu, siswa akan mendapatkan pengalaman belajar secara kontekstual karena belajar memahami dan mengimplementasikan nilai toleransi dan nilai-nilai yang terkandung dalam Pendidikan Multikultural dalam kehidupannya sehari-hari. Dengan adanya pembelalaran nyata inilah, siswa akan terbiasa dan memiliki sikap yang mencerminkan sikap toleransi. Pembelajaran pada akhirnya akan memiliki tujuan kognitif, afektif, dan psikomotor secara keseluruhan.

Berdasarkan pendapat (Jones, 2015), kegiatan pembelajaran multikultural ini akan lebih efektif untuk siswa ketika mereka:

a. Memberikan kesempatan untuk observasi/partisipasi dalam hubungan suatu komunitas;

b. Melibatkan siswa dalam pembelajaran secara langsung dan aktif; 
5759 Implementasi Pendidikan Multikultural melalui Mata Pelajaran PPKn untuk Mendukung Sikap Toleransi Siswa dalam Masyarakat Multikultur - Shilmy Purnama

DOI: https://doi.org/10.31004/basicedu.v5i6.1561

c. Menghubunggkan perhatian siswa secara langsung;

d. Mempercayakan pada materi pelajaran;

e. Memberikan jangkauan dan urutan yang didasarkan;

f. Mengevaluasi dan dokumentasi apa yang sudah dipelajari dengan tes, demonstrasi, survey, dan metode penilaian lainnya.

Kegiatan lain yang bisa mencerminkan pelaksanaan Pendidikan Multikultural di kelas adalah dengan cara mnegenalkan agama, budaya, ras, etnik, bahasa daerah yang dianut oleh siswa. Pengetahuan keberagaman ini membuat siswa tahu dan paham akan keberadaan teman sekelasnya yang berbeda dari segi sosial dan budaya. Setelah tahu akan adanya perbedaan tersebut, maka siswa akan dibimbing untuk saling menghargai dan menampilkan sikap toleransi selama proses pembelajaran di kelas maupun di luar kelas. Selain itu, sekolah akan memperingati hari raya besar keagamaan seperti Idul Fitri, Idul Adha, Natal, dan tahun baru Imlek sehingga seluruh siswa akan ikut merasakan atmosfer perayaan tersebut. Perayaan ini dilakukan di sekolah dan kelas, antar kelas, antar sekolah, atau melibatkan masyarakat sekitar dengan mengadakan festival budaya tahunan, pentas seni, dan pameran.

\section{KESIMPULAN}

Implementasi Pendidikan Multikultural tidak menjadi mata pelajaran sendiri yang terpisah, melainkan diintegrasikan ke dalam mata pelajaran PPKn. Penerapannya diawali dengan merumuskan perencanaan pembelajaran berupa RPP dengan cara melakukan analisis KI-KD, memilih materi mana yang cocok disisipkan nilai Pendidikan Multikultural sehingga tercermin dalam tujuan pembelajaran dan indikator pencapaian kompetensinya. Setelah itu, dalam proses pelaksanaan pembelajarannya pun, guru bisa menyampaikan materi yang telah dipilih yang berkaitan dengan Pendidikan Multikultural seperti keberagaman Indonesia, atau materi umum. Materi umum diterapkan dengan metode diskusi atau simulasi yang tetap mencerminkan nilai-nilai toleransi sebagai perwujudan dari Pendidikan Multikultural. Selain itu, siswa juga bisa mempelajari baju daerah, rumah adat, bahasa daerah, dan lagu daerah lain berdasarkan asal daerah dari teman sekelasnya. Kegiatan lain yang bisa mencerminkan pelaksanaan Pendidikan Multikultural di kelas adalah dengan cara mengenalkan agama, budaya, ras, etnik, bahasa daerah yang dianut oleh siswa.

\section{DAFTAR PUSTAKA}

Al Hakim, S., \& Untari, S. (2018). Pendidikan Multikultural Strategi Inovatif Pembelajaran Dalam Pluralitas Masyarakat Indonesia (M. Media (Ed.)).

Aly, A. (2005). Pendidikan Multikultural Dalam Tinjauan Pedagogik.

Bank, J. (1984). Teaching Strategies For Ethnic Studies. Allyn And Bacon.

Banks, J. A., \& Banks, C. A. M. (2013). Multicultiral Education Issues And Perspectives (Eight). John Wiley And Sons.

Blum, L. (2001). Antirasisme, Multikulturalisme, Dan Komunitas Antar Ras, Tiga Nilai Yang Bersifat Mendidik Bagi Sebuah Masyarakat Multikultur (S. C. Dan D. Rusbiantoro (Ed.)). Tiara Wacana.

Budimansyah, D., \& Suryadi, K. (2008). Pkn Dan Masyarakat Multikultural. Program Studi Pendidikan Kewarganegaraan.

Huberman, M. And. (2014). Qualitative Data Analysis A Methods Sourcebook Edition 3. Sage Publications.

Jones, J. (2015). Infusing Multicultural Education Into The Curriculum: Preparing Pre-Service Teachers To Address Homophobia In K-12 Schools. Http://Ijme-Journal.Org/Index.Php/Ijme 
5760 Implementasi Pendidikan Multikultural melalui Mata Pelajaran PPKn untuk Mendukung Sikap Toleransi Siswa dalam Masyarakat Multikultur - Shilmy Purnama

DOI: https://doi.org/10.31004/basicedu.v5i6.1561

Kalidjernih, F. (2010). Puspa Ragam Konsep Dan Isu Kewarganegaraan. Widya Aksara Press.

Kariyadi, D., \& Suprapto, W. (2017). Membangun Kepemimpinan Berbasis Nilai-Nilai Pancasila Dalam Perspektif Masyarakat Multikultural. Citizenship Jurnal Pancasila Dan Kewarganegaraan, 5(2), 86. Https://Doi.Org/10.25273/Citizenship.V5i2.1560

Meinarno, E. A. (2011). Manusia Dalam Kebudayaan Masyarakat. Salemba Humanika.

Nur Hidayah, M. S. (2006). Masyarakat Multiultural. Masyaraat Multikultural Multikultural, 1-15.

Parekh, B. (2008). Rethinking Multiculturalism Keberagaman Budaya Dan Teori Politik. Kanisius.

Savage, T. V., \& Armstrong, D. G. (1996). Effective Teaching In Elementary Social Studies. Prentice Hall.

Setiawan, D. (2014). Kapita Selekta Kewarganegaraan. Cahaya Ilmu Press.

Supardan, D. (2004). Pembelajaran Sejarah Berbasis Pendekatan Multikultural Dan Perspektif Sejarah Lokal, Nasional, Global, Untuk Integrasi Bangsa (Studi Kuasi Eksperimental Terhadap Siswa Sekolah Menengah Umum Di Kota Bandung). Universitas Pendidikan Indonesia.

Suparlan, P. (2002). Menuju Masyarakat Indonesia Yang Multikultural. In Antropologi Indonesia (P. 98).

Suparlan, P. (2004). Masyarakat Majemuk, Masyarakat Multikultural, Dan Minoritas: Memperjuangakan Hak-Hak Minoritas. Workshop Yayasan Interseksi, Hak-Hak Minoritas Dalam Landscape Multikultural, Mungkinkah Di Indonesia.

Tillman, D. (2004). Pendidikan Nilai Untuk Kaum Muda Dewasa. Grasindo.

Winataputra, U. (2012). Pendidikan Kewarganegaraan Dalam Perspektif Pendidikan Untuk Mencerdaskan Kehidupan Bangsa (Gagasan, Instrumentasi, Dan Praksis). Widya Aksara Press.

Winataputra, U. (2015). Pendidikan Kewarganegaraan Refleksi Historis-Epistemologis Dan Rekonstruksi Untuk Masa Depan. Universitas Terbuka. 